\title{
APLIKASI AUTOMATISASI KILO WATT HERTZ PADA PEMAKAIAN DAYA LISTRIK DENGAN PC MENGGUNAKANDUAL TONE MULTIPLE FREQUENCY (DTMF)
}

\author{
Wincoko,ST,M.Kom
}

\begin{abstract}
ABSTRAK
Membuat perangkat keras dan perangkat lunak yang berbasis mikrokontroler 89C51 dengan PC menggunakan Dual Tone Multiple Frequency (DTMF). Melakukan pengukuran daya dengan menggunakan perangkat keras (hardware) dan perangkat lunak (software). Membuat rangkaian kwh meter digital yang dapat digunakan untuk pemakaian daya yang relatif besar. Mengimplementasikan sistem informasi pulsa daya listrik dengan PHP dan MYSQL dalam pengembangan suatu aplikasi berbasis web.

Alat ini mampu menampilkan banyaknya daya listrik yang dipakai, banyaknya sisa pulsa/daya dan nomor pin voucher yang telah diisikan. Selain itu alat ini mempunyai beberapa kelebihan yaitu mempergunakan komunikasi dengan sistem DTMF (Dual Tone Multiple Frekuensi) dan nilai daya dan pengisian pulsa dapat dipakai menggunakan sistem pada aplikasi Automatisasi pemakaian daya listrik
\end{abstract}

Kata Kunci: DTMF, KWH meter, Aplikasi Automatisasi

\section{PENDAHULUAN}

Perkembangan teknologi memberikan manfaat bagi kehidupan manusia dalam kehidupan sehari-hari. Dengan kemajuan teknologi, banyak peralatan yang dialihkan dari bentuk manual ke bentuk otomatis. Peralatan manual mempunyai kekurangan dalam hal kecepatan, ketepatan dan ketelitian, sehingga peralatan manual tidak dapat diandalkan lagi dan mulai dialihkan menjadi peralatan yang lebih otomatis. Misalnya dalam pengukuran daya listrik, untuk mengetahui berapa kwh yang dipakai dibutuhkan seorang manusia yang harus melakukan pencatatan secara kontinyu.Untuk mengatasi ketidak efisienan ini, maka penyusun berusaha merancang Kwh meter digital untuk aplikasi automatisasi pencatat pemakaian daya listrik. Alat ini mampu menampilkan banyaknya daya listrik yang dipakai, banyaknya sisa pulsa/daya dan nomor pin voucher yang telah diisikan. Selain itu alat ini mempunyai beberapa kelebihan yaitu mempergunakan komunikasi dengan sistem DTMF (Dual Tone Multiple Frekuensi) dan nilai daya dan pengisian pulsa dapat dipakai menggunakan sistem internet.

Sistem ini merupakan pengembangan dari alat kwh meter yang sudah ada, hanya saja sistem ini mengoptimalkan penggunaan mikrokontroler 89C51 yang sudah umum dipasaran.

Dengan sistem ini pelanggan akan merasakan kemudahan dalam hal berlangganan daya listrik. Sekarang pelanggan dapat secara terus-menerus mengontrol pemakaian daya melalui display dirumah atau kamar masing-masing. 


\section{PERANCANGAN SISTEM}

Sistem "Kwh meter Digital untuk Aplikasi Automatisasi Pencatat Pemakaian Daya Listrik Apartemen " merupakan bagian dari "Sistem Listrik Pra Bayar" yang lebih kompleks. Diagram blok sistem secara keseluruhan ditunjukkan pada gambar 3. 1 :

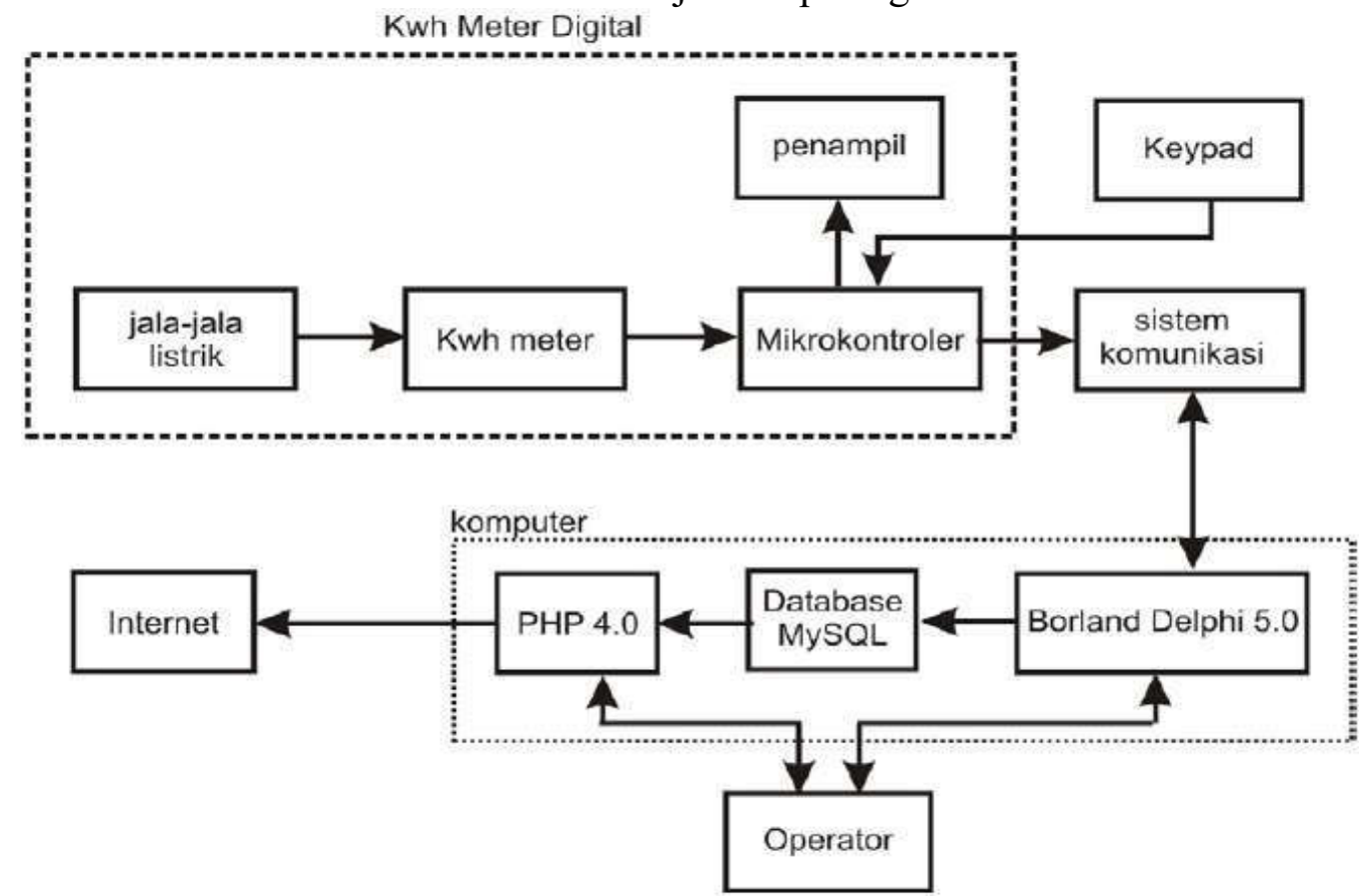

Gambar 3. 1 Diagram blok Sistem Listrik Pra Bayar

Fungsi dari tiap-tiap blok diagram secara singkat adalah sebagai berikut :

- Jala-jala listrik merupakan jalur yang akan diukur dayanya.

- Kwh meter Digital

Merupakan piranti yang akan melakukan pengukuran dan pengolahan perubahan daya litstrik. Pada bagian ini terdiri atas rangkaian detektor, rangkaian pengali, rangkaian penyangga pembalik, rangkaian Voltage Controlled Oscilator/VCO dan mikrokontroler sebagai bagian pengolah utama serta rangkaian penampil.

- Sistem Komunikasi

Sarana pengiriman data antara komputer dan mikrokontroler. Sistem pengiriman data menggunakan sistem Dual Tone Multiple Frekuensi /DTMF

- Borland Delphi 5.0

Sebagai antarmuka antara tranceiver DTMF dan PC

- Komputer

Menyimpan dan mengolah data meter Kwh terukur dari tiap-tiap kamar, dan mengatur komunikasi data komputer dengan mikrokontroller dengan menggunakan bahasa pemrograman Delphi dan Turbo Pascal .

- MySQL

Sebagai basis data penyimpanan data meter kwh terukur, sisa pulsa dan kode pulsa serta data pelanggan.

- PHP

Sebagai sarana hubungan antara server dengan pelanggan melalui internet

- Internet 
Merupakan sarana untuk menghubungkan alat ke dunia luar, sehingga dapat diakses secara luas baik itu nomor pin, data pelanggan listrik, pemakaian daya dan sisa pulsa.

- Operator

Sebagai pengatur semua piranti dari nilai rupiah setiap kwh, data dan nomor kamar pelanggan sampai penyambungan kembali jika terjadi pemutusan aliran listrik. Sistem "Kwh meter Digital untuk Aplikasi Automatisasi Pencatat Pemakaian Daya Listrik Apartemen " terdiri atas bagian bagian sebagai berikut :

- Detektor tegangan

Mengubah tegangan 220 VAC menjadi tegangan 3 VAC

- Detektor arus

Mengubah setiap perubahn arus yang mellui beban menjadi perubahan tegangan.

- Pengali tegangan

Mengalikan tegangan dari kedua detector agar didptkan perubahan tegangan sesuai dengan perubahan day terukur.

- Voltage Controlled Oscilator VCO

Mengubah perubahan tegangan menjadi perubahan frekuensi

- Mikrokontroller 89C51

Menghitung data hasil pengukuran yang berupa perubahan frekuensi dari rangkaian VCO, mengolah mengirimkan ke DTMF dan menampilkan melalui display.

Gambar diagram blok Sistem Kwh meter ditunjukkan pada gambar 3. 2 :

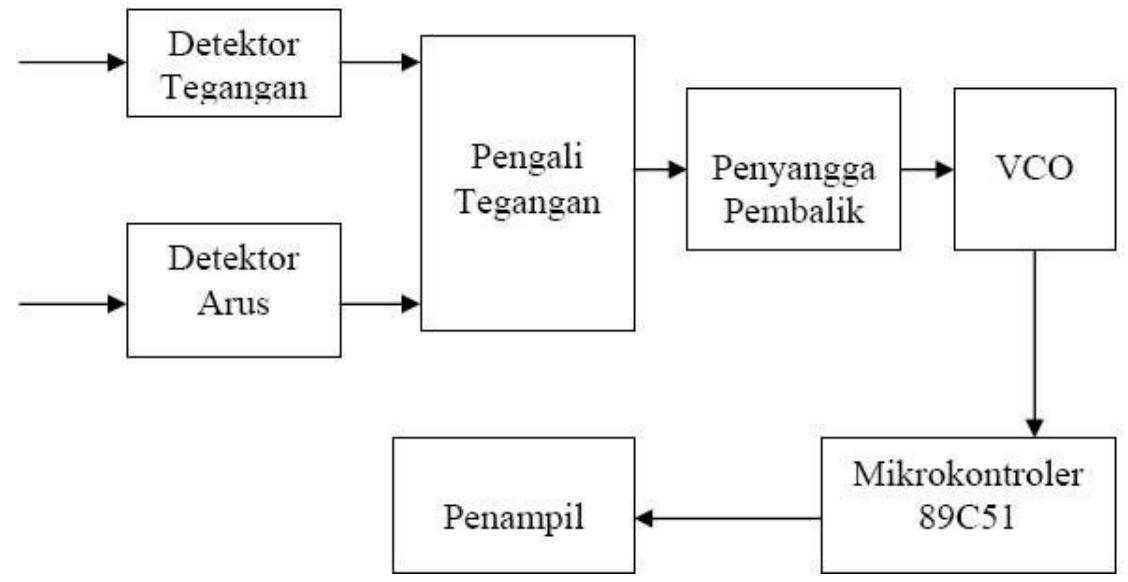

Gambar 3. 2 Diagram blok Sistem Kwh meter digital (Sumber: M. Nurul Hudha)

Perancangan Sistem "Kwh meter Digital untuk Aplikasi Automatisasi Pencatat

Pemakaian Daya Listrik Apartemen " terdiri atas dua bagian, yaitu perancangan perangkat keras (hardware) dan bagian perancangan perangkat lunak (software). 


\section{Perancangan Perangkat Keras \\ Rangkaian Detektor}

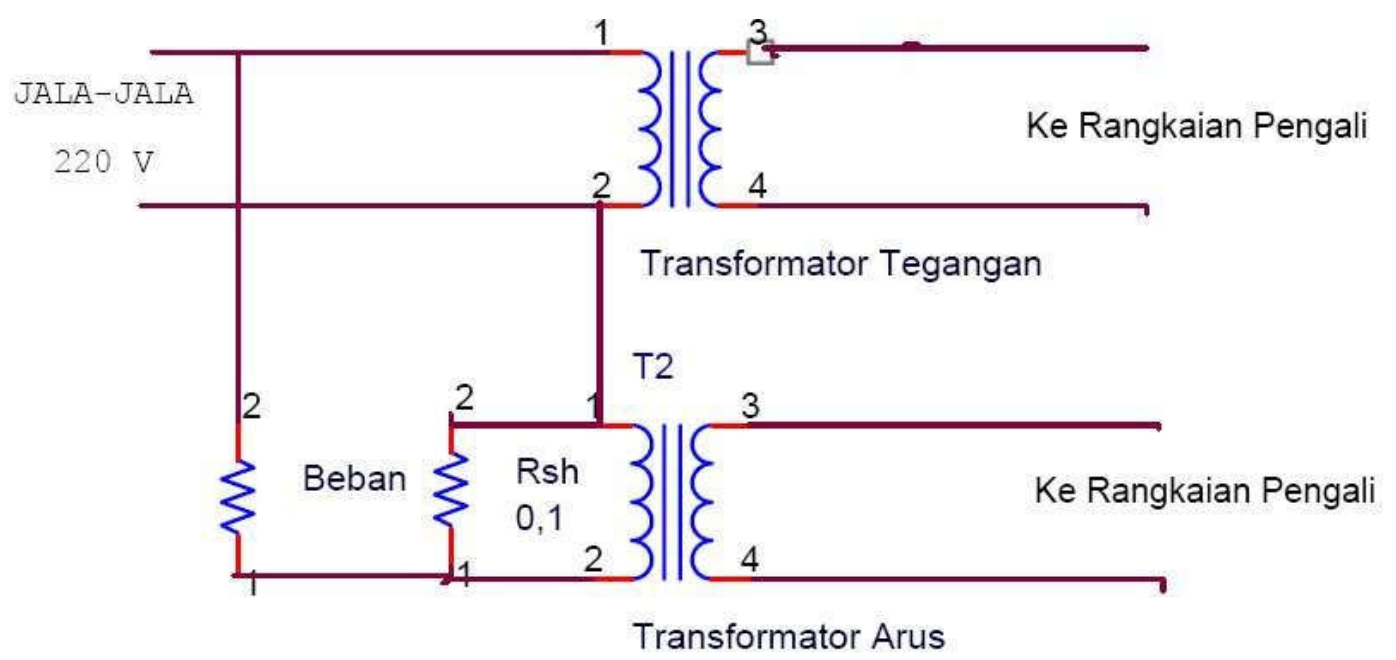

Gambar 3. 3 Rangkaian detektor tegangan dan arus (Sumber: M. Nurul Hudha)

\section{Transformator Tegangan}

Komponen utama detektor tegangan yang berupa transformator akan mengubah tegangan jala-jala PLN sehingga dapat di umpankan ke rangkaian pengali. Transformator difungsikan sebagai Transformator penurun tegangan (step down). Tegangan jala-jala PLN 220 Volt AC akan diturunkan sampai level tertentu sehingga dapat menjadi masukan parameter tegangan (V) pada rangkaian pengali (multiplier).

\section{Transformator Arus}

Parameter arus (I) didapatkan dengan cara melewatkan arus yang mengalir melalui kumparan sekunder transformator. Setiap perubahan beban akan menyebabkan perubahan arus yang mengalir pada kumparan sekundernya. Dengan induksi elektromagnetik perubahan arus pada kumparan sekunder akan menyebabkan perubahan tegangan pada kumparan primer. Besar level tegangan pada kumparan keluaran ini dapat dibatasi dengan cara memberi hambatan seri (resistor shunt) pada kumparan masukan .

\section{Rangkaian Pengali}

Isyarat keluaran dari detektor tegangan dan detektor arus diumpan ke rangkaian pengali A5. Otak dari pengali adalah OTA 13600 atau 13700. OTA menguatkan tegangan diferensial yang dikenakan dijalan masuknya (pin 13 dan 14) dan mengeluarkan arus, di keluaran (pin 12). Faktor penguatannya dinyatakan dalam $\mathrm{mA} / \mathrm{V}$ dan disebut sebagai transkondukstansi (gm). Lereng transkondukstansi ini relatif linear dan berubah sebagi fungsi arus (kemudi) yang mengalir di pin 16. Jadi OTA menguatkan dua variabel dan menguatkan arus sebagai hasil kalinya. Disini satu variabel adalah tegangan yang disadap dari jaringan dan diuibah menjadi arus kemudi oleh P2 dan R16. Dan variabel kedua adalah tegangan yang dihasilkan arus beban lewat R4. Rangkaian OTA 13600 sebagai pengali tegangan ditunjukkan pada gambar 3.2: 


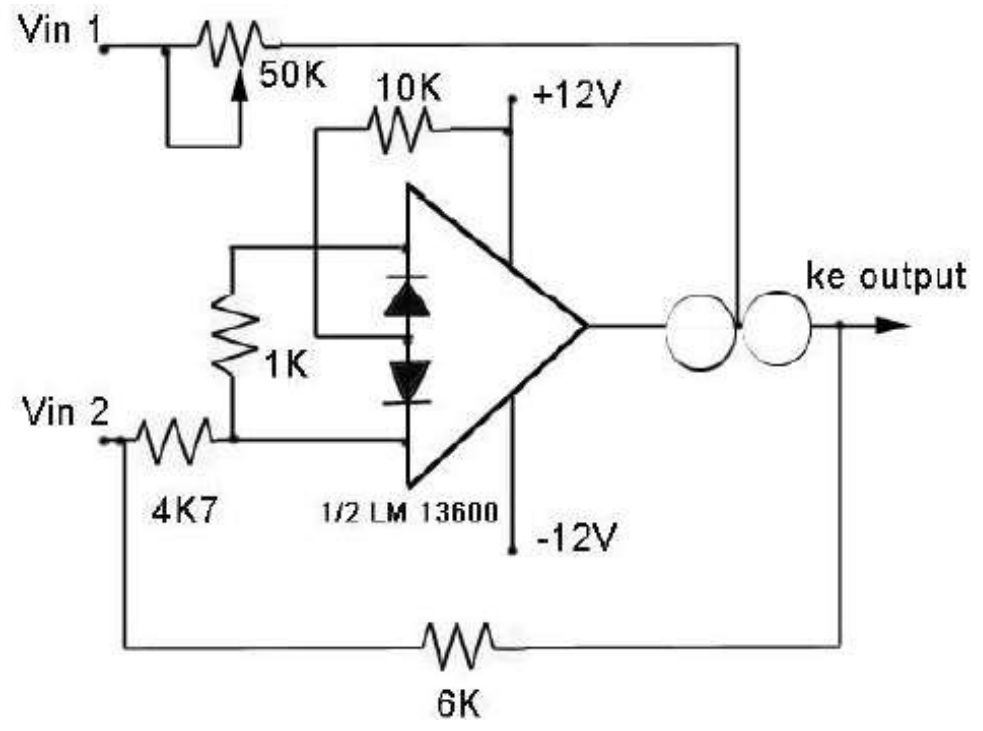

Gambar 3. 2 Rangkaian OTA 13600 sebagai pengali (Sumber: M. Nurul Hudha).

\section{Penyangga Pembalik}

Rangkaian ini disusun dari sebuah penguat operasional LM 741. Penyangga/Buffer dalam hal ini akan berfungsi sebagai isolator dimana Rin rangkaian Voltage Controlled Oscilator/VCO tidak akan membebani rangkaian pengali. Jika tanpa menggunakan penyangga/buffer maka sinyal yang keluar dari rangkaian pengali yang masuk ke op-amp akan hilang. Hal in disebabkan nilai hambatan R pada op-amp begitu besar. Dengan nilai $\mathrm{R}$ in yang besar $\mathrm{Rin}=\sim$ rangkaian seakan-akan terputus (short) sehingga sinyal tetap ada sedang dengan nilai Rout yang kecil Rout $=0$ akan tetap melewatkan sinyal. Hambatan Rin dan Rout sama nilainya, hal ini dimaksudkan untuk menghasilkan penguatan sebesar 1 kali. Nilai Rin $=10 \mathrm{~K} \Omega$ sedangkan Rout menggunakan sebuah variabel resistor sehingga nilainya dapat benar-benar ditentukan sesuai hambatan Rin. Gambar rangkaian penyangga pembalik ditunjukkan pada gambar 3.3:

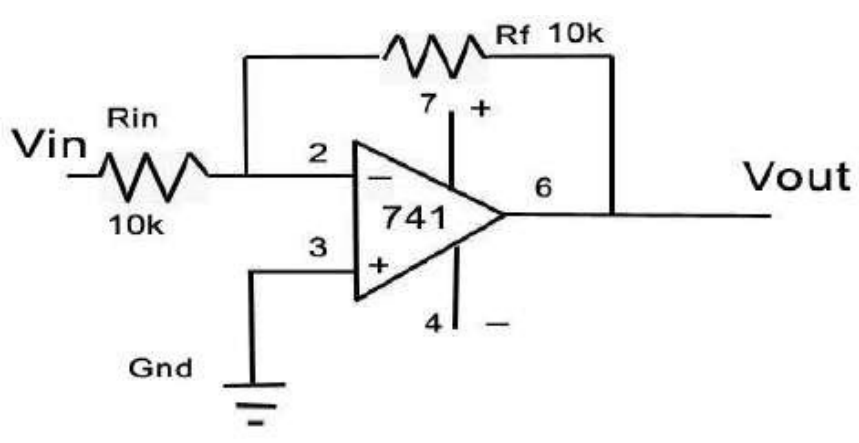

Gambar 3. 3 Untai penyangga pembalik (Sumber: M. Nurul Hudha)

\section{Osilator Terkendali Tegangan/Voltage Controlled Oscilator (VCO)}

Osilator yang dikendalikan tegangan (voltage cotrolled oscillator/VCO) ini mampu mengeluarkan gelombang segitiga dan kotak. Seperti VCO yang lain maka disinipun frekuensi keluaran ditentukan oleh besar kecilnya tegangan kontrol Vc. 


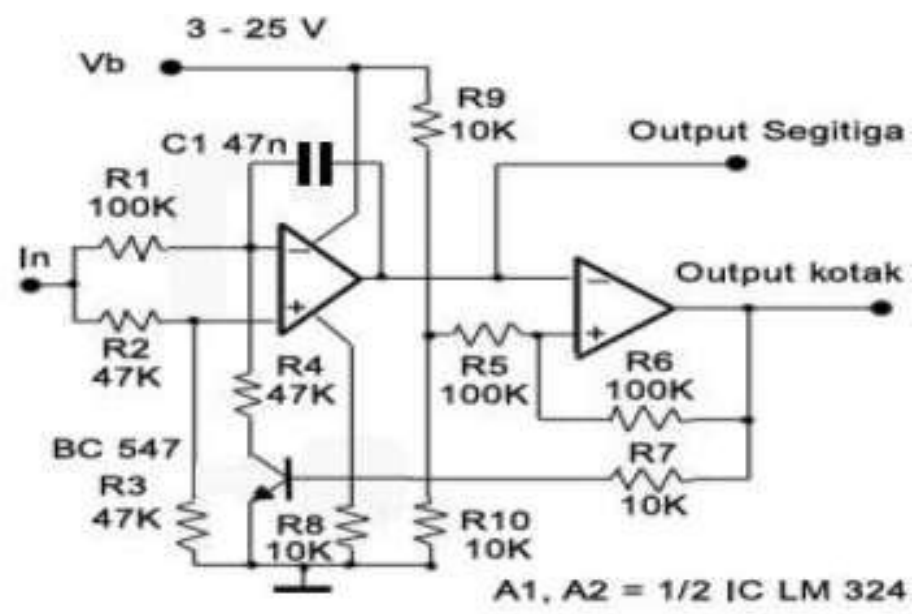

Gambar 3. 4 Rangkaian Voltage Controlled Oscilatior/VCO

\section{Sistem Minimum Mikrokontroller 89C51}

Sistem minimum mikrokontrollr Atmel 89C51 harus memiliki spesifikasi tertentu sebagai berikut:

1. Memiliki mikrokontroller 89C51 yang mempunyai tugas melakukan pengolahan data daya yang terbaca melalui masukan counter dan ditampilkan ke display.

2. Port 0 digunakan untuk menampilkan pengolahan data daya listrik dengan menggunakan 8 digit seven segmen display

3. Port 1 digunakan untuk komunikasi dengan PC dengan menggunakan Dual tone Multiple Frekuensi DTMF

4. Port 2 digunakan untuk sistem keypad untuk memasukan data, interupsi dan sebagainya.

5. Port 3 digunakan untuk masukan data pengukuran daya listrik dari rangkaian VCO menggunakan sarana timer/counter. 


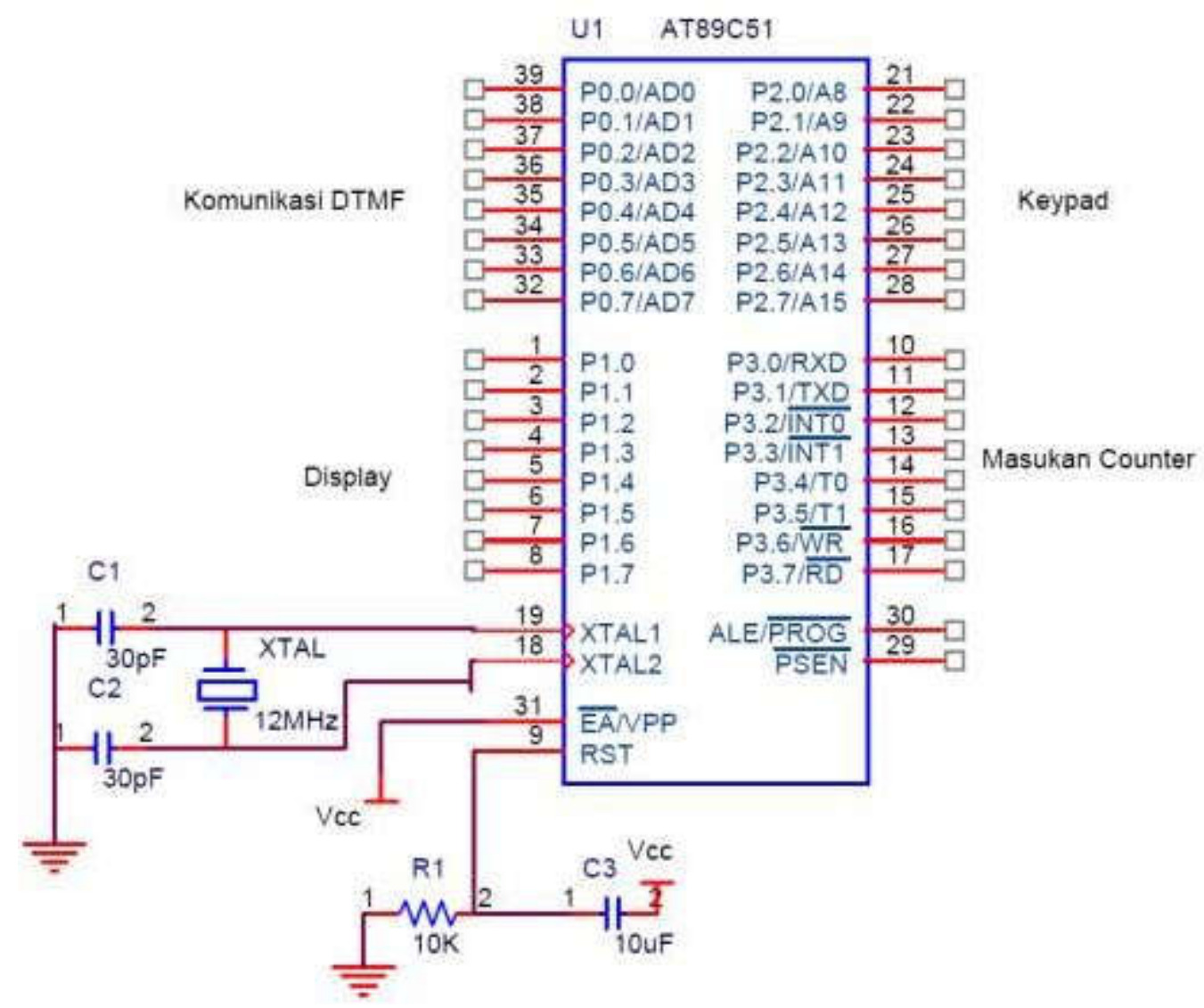

Gambar 3. 1 Sistem minimum mikrokontroler 89C51 (Sumber: M. Nurul Hudha)

\section{Timer/Counter 89C51}

Sarana masukan dengan counter/timer ini merupakan seperangkat pencacah biner (binary counter) yang terhubung ke saluran data mikrokontroler, sehingga mikrokontroler dapat membaca kondisi pencacah dan bila diperlukan mikrokontroler dapat pula mengubah kondisi pencacah tersebut.

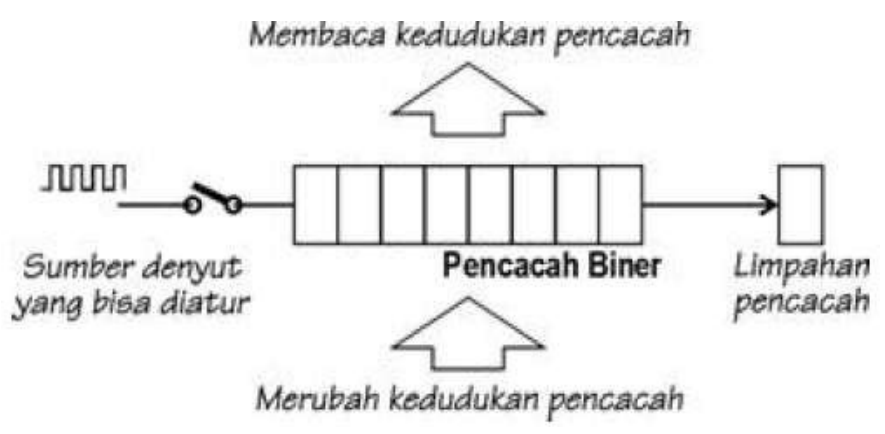

Gambar 3. 4 Konsep dasar Timer/Counter sebagai sarana input

Pencacah bekerja sebagai timer, jika sebuah pencacah bekerja dengan frekuensi tetap yang sudah diketahui besarnya, karena kedudukan pencacah tersebut setara dengan waktu yang bisa ditentukan dengan pasti. Pencacah bekerja sebagai counter, jika sebuah pencacah bekerja dengan frekuensi yang tidak tetap, kedudukan pencacah tersebut hanyalah menyatakan banyaknya pulsa yang sudah diterima pencacah. Keluarga mikrokontroler 
MCS51, misalnya AT89C51 dan AT89Cx051, dilengkapi dengan dua perangkat Timer/Counter, masing-masing dinamakan sebagai Timer 0 dan Timer 1. Perangkat Timer/Counter tersebut merupakan perangkat keras yang menjadi satu dalam chip mikrokontroler MCS51, bagi pemakai mikrokontroler MCS51 perangkat tersebut dikenal sebagai SFR (Special Function Register) yang berkedudukan sebagai memori-data internal. Gambar 3. 5 merupakan bagan susunan rangkaian yang bisa terjadi pada Timer 1 secara lengkap, digambarkan pula hubungan-hubungan semua register pembentuk dan pengatur Timer 1 .

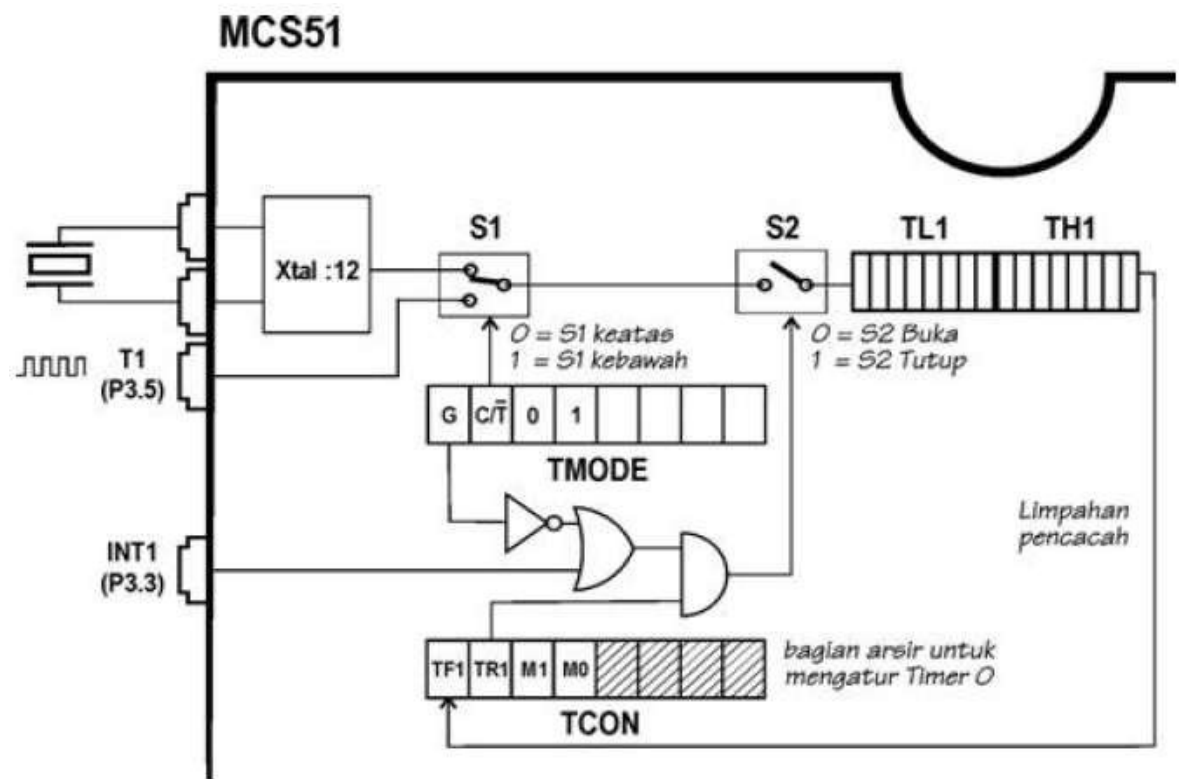

Gambar 3. 5 Skema lengkap Timer 1 dalam Mode 1 (Sumber: M. Nurul Hudha)

\section{Penampil (display)}

Penampil yang digunakan adalah seven segmen anoda dengan penggerak/ dekoder BCD ke seven segmen 74LS47. Penampil berfungsi untuk menampilkan data daya listrik, sisa pulsa dan nomor pin voucher yang diisikan ke alat yang telah diubah dari bentuk bilangan heksadesimal ke bilangan desimal sehingga mudah dibaca (user friendly) manusia sebagai pemakai (user). Karena penampilan data menggunakan port 0 yang hanya memiliki delapan pin, sedangkan data yang akan ditampilkan berupa data delapan digit, maka diperlukan rangkaian penggerak/driver 3 ke 8. Gambar rangkaian penampil dengan penggerak/ driver dapat ditunjukkan pada gambar 3. 6 .

\section{Catu Daya (Power Supply)}

Rangkaian catu daya dibangun dengan IC seri 78XX yang berfungsi sebagai regulator tegangan. IC 7805 mempunyai tegangan keluaran 5 volt, sedang fungsi transistor 2N3055 adalah sebagai penaik arus, karena IC seri $78 X X$ hanya mmpu memberikan arus maksimal sebesar 1 ampere.

Untuk mengaktifkan rangkaian penguat operasional digunaka rangkaian catu daya simetris. Rangkaian catu daya simetris dibangun dengan IC 78XX unutuk keluaran tegangan positip (+) dan IC 79XX untuk keluaran tegangan negatip (-). Gambar untai rangkaian catu daya ditunjukkan pada gambar 3. 7 . 


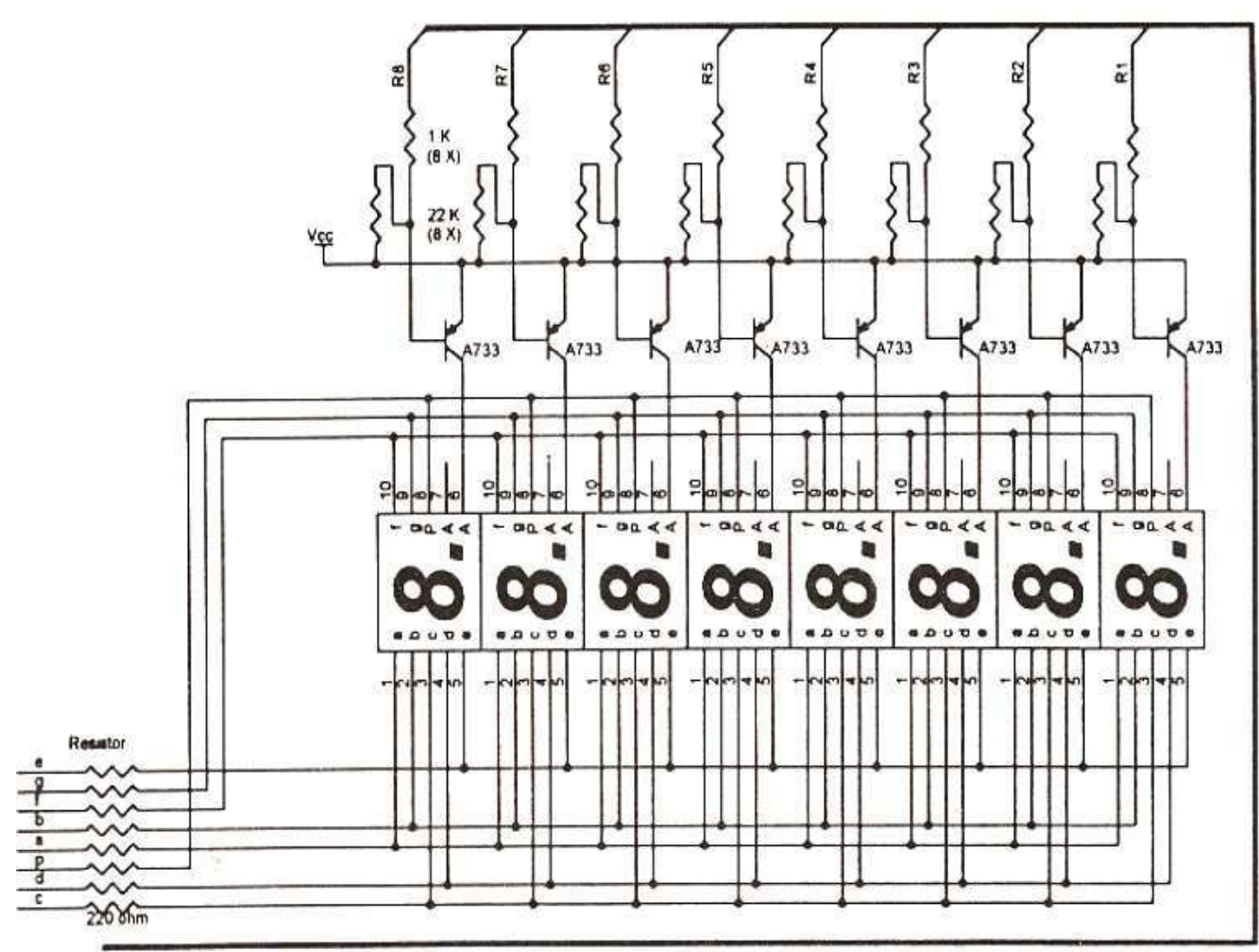

Gambar 3. 6 Untai Rangkaian Penampil

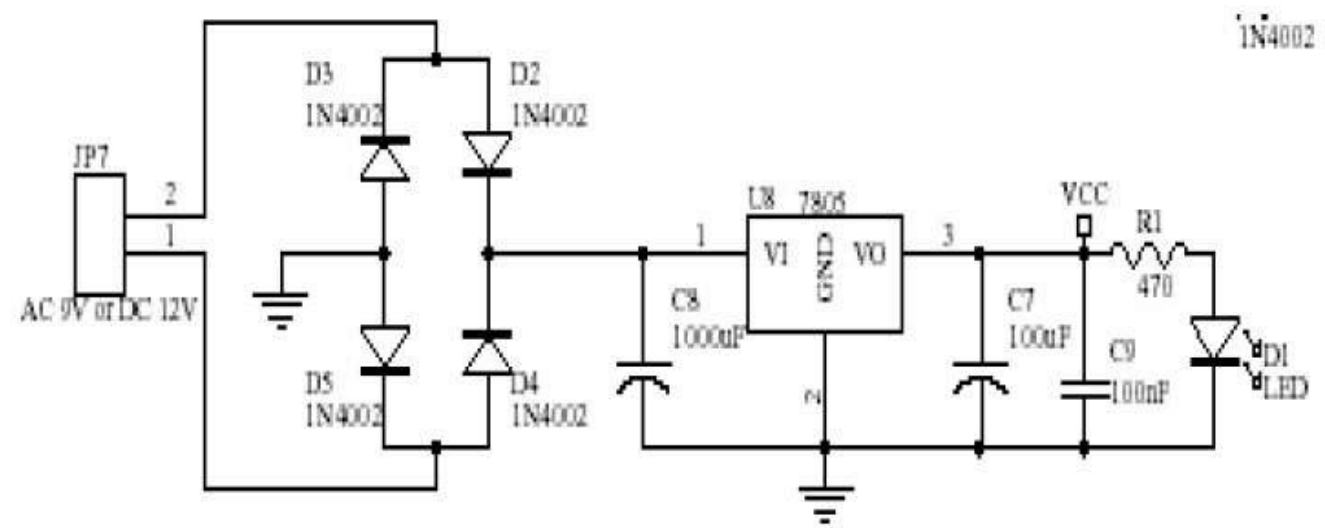

Gambar 3. 7 Untai rangkaian Catu Daya (Sumber: M. Nurul Hudha)

\section{Perancangan Perangkat Lunak}

Perangkat lunak yang dibutuhkan untuk mengubah kode sumber (source code) yaitu file-file yang mempunyai ekstensi .asm menjadi file biner (*.bin) yang dapat dijalankan oleh mikrokontroller 89C51 adalah : ASM51.EXE, OH.EXE dan HEXBIN.EXE. Fungsi dari masing-masing program diatas adalah sebagai berikut:

1. Program ASM51.EXE digunakan untuk mengubah file*.asm menjadi file object (*.obj).

2. Program OH.EXE digunakan untuk mengubah file object (*.obj) menjadi file heksa (*.hex). 
3. Program HEXBIN.EXE digunakan untuk mengubah file heksa (*.hex) menjadi file biner(*.bin).

File biner inilah yang melalui EPROM programmer dimasukkan ke EPROM untuk dijalankan oleh mikrokontroler 89C51. Perangkat lunak dibuat dengan suatu algoritma atau logika pemikiran yang diimplementasikan ke dalam bahasa assembly yang digunakan untuk mengendalikan peralatan atau sistem minimum yang dibuat agar sesuai dengan yang diharapkan.

\subsubsection{Interupt Vector Table}

Program listrik prabayar terdiri atas banyak program yang harus semua dilayani secara adil. Sistem pelayanan bagian-bagian program tersebut dapat dilakukan dengan dua cara, yaitu sistem looping dan sistem interupsi. Pada sistem looping masing-masing sub program akan dipanggil dan dilayani secara terus-menerus dan berurutan, sedang pada sistem interupsi sub-sub program akan dilayani saat sub-sub program tadi menginterupsi program utama. Pada sistem looping, program utama akan secara aktif melakukan pelayanan pada tiap-tiap sub-sub program. Pada sistem ini terdapat beberapa kelemahan, selain tidak efisien waktu juga tidak adanya prioritas progam yang akan dilayani. Pada sistem interupsi bagianbagian program akan secara aktif melakukan interupsi tanpa harus menunggu giliran pelayanan dari program utama. Prioritas interupsi diatur pada program Interupt Vector Table seperti ditunjukkan pada potongan program berikut :

Org 0000h

Ljmp main

Org $0003 \mathrm{~h}$

Ljmp pelayanan_intr0

Org $000 \mathrm{bh}$

Ljmp increment_counter_gelombang

Org 0013h

Reti

Org $001 b h$

Ljmp tampil

Org $0023 \mathrm{~h}$

Reti

Org 002bh

reti

Prioritas tertinggi interupsi adalah program counter penghitungan daya listrik, kemudian pelayanan komunikasi DTMF dan sistem tampilan pada display.

\section{Program Baca Data Counter gelombang}

Timer/counter diset pada mode 1 dengan perintah TMOD,\#00000101B . Ini berarti bahwa :

Pada Timer 1 -- $\mathrm{GATE}=0, \mathrm{C} /-\mathrm{T}=0, \mathrm{M} 1=0, \mathrm{M} 2=0$

Pada Timer $0-$ GATE $=0, \mathrm{C} /-\mathrm{T}=1, \mathrm{M} 1=0, \mathrm{M} 2=1$

- $\quad$ Bit C/T* ='0', menurut Gambar 4 keadaan ini membuat saklar S1 ke posisi atas, sumber sinyal denyut berasal dari osilator kristal yang frekuensinya sudah dibagi 12 , pencacah biner yang dibentuk dengan TL1 dan TH1 berfungsi sebagai timer. Jika sistem yang dirancang memang menghendaki Timer 1 bekerja sebagai timer maka bit $\mathrm{C} / \mathrm{T}^{*}$ tidak perlu diatur lagi. Tapi jika sistem yang dirancang menghendaki agar Timer 1 bekerja sebagai 
counter untuk menghitung pulsa yang masuk lewat kaki 1 (P3.5), maka posisi saklar S1 harus dikebawahkan dengan membuat bit $\mathrm{C} / \mathrm{T}^{*}$ menjadi ' 1 '.

- Bit GATE='0', hal ini membuat output gerbang OR selalu '1' tidak dipengaruhi keadaan '0' atau '1' pada kaki INT1 (P3.3). Dalam keadaan semacam ini, saklar S2 hanya dikendalikan lewat bit TR1 dalam register TCON. Jika TR1='1' saklar S2 tertutup sehingga sinyal denyut dari S1 disalurkan ke sistem pencacah biner, aliran sinyal denyut akan dihentikan jika TR='0'. Sebaliknya jika bit GATE='1', output gerbang OR akan mengikuti keadaan kaki INT1, saat INT1='0' apa pun keadaan bit TR1 output gerbang AND selalu ='0' dan saklar S1 selalu terbuka, agar saklar S1 bisa tertutup kaki INT1 dan bit TR1 harus ='1' secara bersamaan. Jika sistem yang dirancang menghendaki kerja dari timer/counter dikendalikan dari sinyal yang berasal dari luar chip, maka bit GATE harus dibuat menjadi ' 1 '

- Bit M1 dan M0='0', berarti TL1 dan TH1 disusun menjadi pencacah biner 13 bit (Mode 0), jika dikehendaki Timer 1 bekerja pada mode 1 seperti terlihat dalam Gambar 4, maka bit M1 harus dibuat menjadi ' 0 ' dan bit M0 menjadi ' 1 '.

Program tampilan seven segmaen adalah prioritas yang lebih rendah dan karena karena mikrokontroler 89C51 hanya memiliki satu Timer, maka program tampilan ditumpangkan/disispkan pada timer 1. Hal ini tidak akan berpengaruh karena mata manusia tidak begitu peka terhadap perubahan yang relatif pendek.

Potongan program counter data adalah sebagai berikut :

mov sp,\#6fh

setb ip. 1

mov tmod, $\# 00000101 b$

; counter prioritas tertinggi

setb ea

; Timer 1 mode 013 bit

; counter0 mode 116 bit

; aktifkan sistem interupsi

setb et 1

; Timer1 sbg refreeze tampilan

setb et0

; aktifkan Timer 1

acall convers_gelombang

; aktifkan counter0

mov t10,buffer_gelombangL

mov th0,buffer_gelombangH

setb $\operatorname{tr} 1$

setb tr0

$$
\begin{aligned}
& \text {; hidupkan Timer } 1 \\
& \text {; hidupkan counter } 0
\end{aligned}
$$

\section{Program Pengisian Data}

Pada program ini harga daya listrik setiap kwh dapat ditentukan dengan mudah. Pada progrm untuk mengubah hrga per kwh ataupun yang lain tidak perlu dilakukan dengan mengubah banyak program . Penulisan cukup dilkukan pada nilai yang akan diganti. Hal ini dapat dilakukan karena nilai desimal telah direpresentasikan oleh nilai heksadesimal program. Potongan program yang dapat di ubah oleh operator adlah sebagai berikut:

$\begin{array}{lll}\text { Nomor_kamar } & \text { equ } & 123 \mathrm{~h} \\ \text { Gelombang } & \text { equ } & 2 \\ \text { Harga } & \text { equ } & 150 \mathrm{~h} \\ \text { Voucher_awal-s } & \text { equ } & 0500 \mathrm{~h} \\ \text { Voucher_awal_pr } & \text { equ } & 0000 \mathrm{~h}\end{array}$

\section{HASIL ANALISIS DAN IMPLEMENTASI}


Setelah merancang, membuat alat dan mengukur parameter-parameter tertentu dapat dianalisis sebagai berikut :

\section{Detektor Tegangan}

Transformator tegangan bekerja sebagai transformator penurun tegangan, sehingga tegangan yang terukur pada keluaran detektor tegangan merupakan tegangan keluaran yang tetap, yaitu tegangan bolak-balik 3 volt. Tegangan ini tidak berubah walaupun terjadi perubahan pada beban. Tegangan ini adalah masukan V1 rangkaian pengali sebagai tegangan referensi .

\section{Detektor arus}

Prinsip detektor arus adalah mengubah besaran arus yang mengalir ke dalam bentuk perubahan tegangan. Karena diaplikasikan pada beban sebenarnya, sesuai dengan besarnya beban yang diberikan maka untuk membatasi arus yang mengalir pada beban dipasang resistor. Resistor ini dipasang secara paralel dengan lilitan masukan transformator arus.

\section{Rangkaian Pengali}

Isyarat keluaran dari detektor tegangan dan detektor arus diumpan ke rangkaian pengali setelah sebelumnya telah disearahkan oleh komponen dioda yang ada pada internal IC OTA 13600 . Otak sebagai dari pengali OTA 13600 atau 13700 menguatkan tegangan diferensial yang dikenakan di masukannya (pin 13 dan 14) dan mengeluarkan arus, di keluaran (pin 12). Faktor penguatannya dinyatakan dalam $\mathrm{mA} / \mathrm{V}$ dan disebut sebagai transkondukstansi (gm). Lereng transkondukstansi ini relatif linear dan berubah sebagi fungsi arus (kemudi) yang mengalir di pin 16. Jadi OTA menguatkan dua variabel dan mengeluarkan arus sebagai hasil kalinya. Disini satu variabel adalah tegangan yang disadap dari jaringan dan diubah menjadi arus kemudi oleh P2 dan R16. Dan variabel kedua adalah tegangan yang dihasilkan arus beban lewat R4.

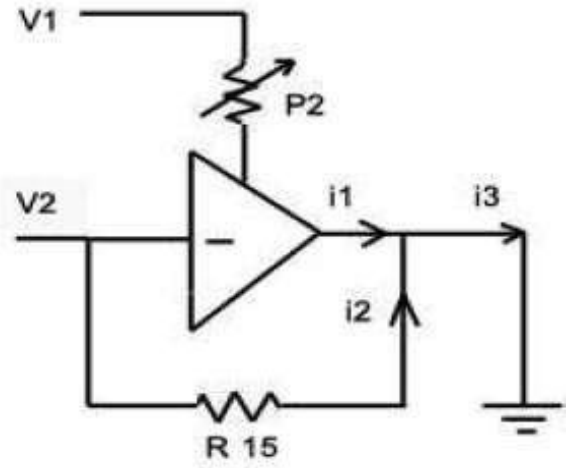

Gambar 4. 1 Diagram rangkaian ekivalen OTA sebagai pengali.

Pada gambar tersebut OTA digambarkan sebagai penguat dengan lereng gm. Tegangan yang dijabarkan dari arus beban ditandai dengan V2 . Lereng gm dari OTA menjungkirkan disetel dengan P2. Rangkaian ini menghasilkan arus i3 yang mengalir ke ground sasis (atau tepatnya ground semu). Besarnya i3 dapat dihitung sebagai berikut :

$$
\begin{aligned}
& \mathrm{i} 3=\mathrm{i} 1+\mathrm{i} 2 \\
& \mathrm{i} 3=-(\mathrm{gm}+\mathrm{gm} 0) \times \mathrm{V} 2+\frac{\mathrm{V} 2}{\mathrm{R} 15} \\
& \quad \text { gmo }=\text { lereng pada V1 }=0 \\
& \quad \mathrm{gm}=\mathrm{k} \times \mathrm{V} 1(\mathrm{k}=\text { konstanta })
\end{aligned}
$$




$$
\begin{aligned}
& \mathrm{i} 3=-(\mathrm{kxV} 1+\mathrm{gm} 0) \times \mathrm{V} 2+\frac{\mathrm{V} 2}{\mathrm{R} 15} \\
& \mathrm{i} 3=-\mathrm{k} \times \mathrm{V} 1 \times \mathrm{V} 2-\mathrm{gm} 0 \times \mathrm{V} 2 \frac{\mathrm{V} 2}{\mathrm{R} 15}
\end{aligned}
$$

Kalau P2 disetel sehingga gm0 $=\underline{1}$

$$
\begin{aligned}
& 13=-\mathrm{k} \times \mathrm{V} 1 \times \mathrm{V} 2-\underline{\mathrm{V} 2}+\underline{\mathrm{V} 2} \\
& \mathrm{I} 15=\quad-\mathrm{k} 15 \mathrm{~V} 1 \times \mathrm{V} 2
\end{aligned}
$$

Sedangkan tata urutan pengetriman adalah sebagai berikut :

1. Pengetriman P2, Vin 1 diberi tegangan nol volt atau hubung ke ground.Vin 2 diberikan sembarang tegangan konstan. Kemudian P2 diatur sehingga Vout nol volt.

2. Pengetriman P1, kebalikan dari langkah pertama yakni Vin 2 dihubung ke ground dan Vin 1 diberi tegangan konstan. Kemudian P1 diatur sehingga Vout juga nol volt.

3. Pengetriman P1 dan P2 dilakukan beberapa kali untuk mendapatkan hasil yang optimal.

Tegangan output pengali di pin 12 dengan berbagai harga tegangan input dapat dihat pada tabel 4.1 :.

Tabel 4. 1 Hasil pengukuran keluran pengali untuk beberapa tegangan input

\begin{tabular}{|c|c|c|c|c|c|c|c|c|}
\hline \multicolumn{2}{|c|}{ Vout (v) } & \multicolumn{7}{|c|}{ Vin 1 (v) } \\
\cline { 2 - 9 } & -3 & -2 & -1 & 0 & 1 & 2 & 3 \\
\hline \multirow{5}{*}{ Vin2 (v) } & -3 & $-0,71$ & $-0,41$ & $-0,16$ & 0,03 & 0,3 & 0,5 & 0,7 \\
\cline { 2 - 9 } & -2 & $-0,43$ & $-0,26$ & $-0,08$ & 0,05 & 0,25 & 0,42 & 0,59 \\
\cline { 2 - 9 } & -1 & $-0,20$ & $-0,10$ & $-0,05$ & 0,04 & 0,15 & 0,24 & 0,32 \\
\cline { 2 - 9 } & 0 & 0 & 0 & 0 & 0 & 0 & 0 & 0 \\
\cline { 2 - 9 } & 1 & 0,24 & 0,13 & 0,07 & $-0,04$ & $-0,15$ & $-0,24$ & $-0,32$ \\
\cline { 2 - 9 } & 2 & 0,46 & 0,27 & 0,10 & $-0,01$ & $-0,24$ & $-0,41$ & $-0,59$ \\
\cline { 2 - 9 } & 3 & 0,69 & 0,41 & 0,15 & $-0,03$ & $-0,36$ & $-0,62$ & $-0,87$ \\
\hline
\end{tabular}

Berdasarkan tabel diatas, dapat dibuat grafik transfer karakteristik pengali empat kuadran menggunakan OTA 13600 pada gambar 4.2 sebagai berikut :

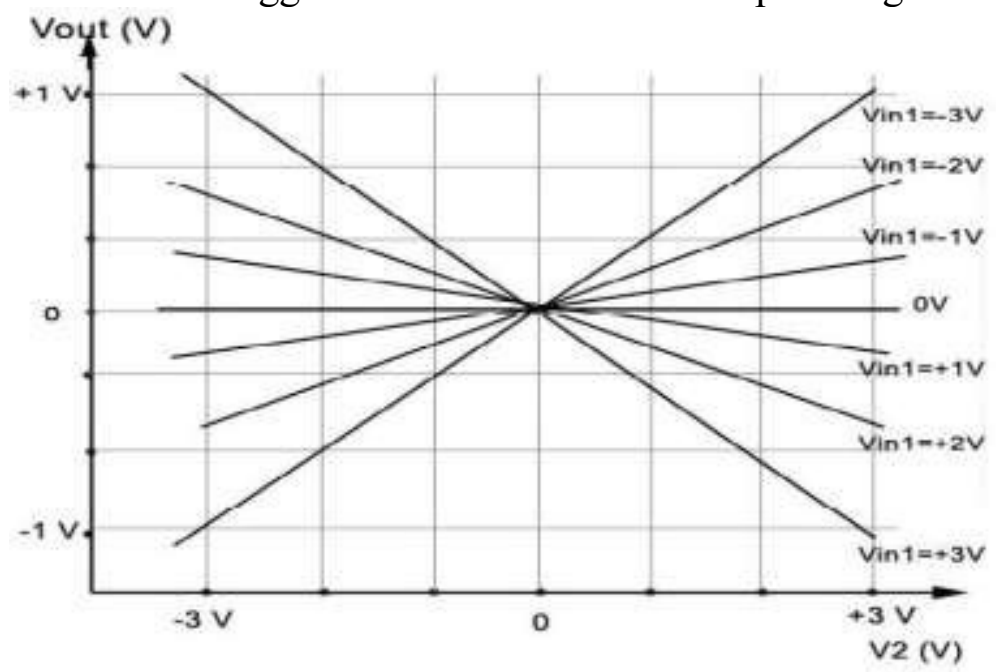

Gambar 4. 2 Grafik transfer karakteristik pengali empat kuadran OTA 13600 


\subsection{Rangkaian Penguat Pembalik}

Keluaran dari rangkaian pengali adalah tegangan terbalik (negatif), maka diperlukan suatu rangkaian pembalik yang sekaligus berfungsi sebagai penyangga (buffer). Penyangga (buffer) mempunyai karakteristik :

$$
\begin{aligned}
& \text { Rin }=\sim \\
& \text { Rout }=0 \\
& -A=\frac{\text { Rout }}{\text { Rin }}
\end{aligned}
$$

Karena penguatan yang diperlukan adalah sebesar 1 kali, nilai hambatan Rin dan Rout harus sama :

$$
\begin{aligned}
-\mathrm{A} & =\frac{1}{1} \\
& =-1 \text { kali }
\end{aligned}
$$

Untuk beberapa contoh beban dapat dibandingkan hasilk pengukuran dengan perhitungan sebagai berikut :

Pada beban $10 \mathrm{~W}$, diketahui :

$$
\begin{aligned}
\text { Vin } & =-24 \\
\text { Rin } & =10 \mathrm{~K} \\
\text { Rf } & =10 \mathrm{~K} \\
\text { Vout } & =-\frac{\text { Rf }}{\operatorname{Rin}} \text { Vin } \\
& =-\frac{10 \mathrm{~K}}{10 \mathrm{~K}}-24 \mathrm{v} \\
& =24 \text { volt }
\end{aligned}
$$

Pada rangkaian digunakan Resistor dengan nilai hambatan $10 \mathrm{~K} \Omega$ dan sebuah variable resistor yang dapat diubah nilai hambatannya. Penggunaan variable resistor dipilih karena untuk mempermudah menentukan nilai hambatan yang sama dengan hambatan Rout. Buffer dalam hal ini akan berfungsi sebagai isolator dimana Rin rangkaian VCO tidak akan membebani rangkaian pengali. Jika tanpa menggunakan buffer maka sinyal yang keluar dari rangkaian pengali yang masuk ke op-amp akan hilang. Hal in disebabkan nilai hambatan $\mathrm{R}$ pada op-amp begitu besar. Dengan nilai $\mathrm{R}$ in yang besar $\mathrm{Rin}=\sim$ rangkaian seakan-akan terputus (short) sehingga sinyal tetap ada sedang dengan nilai Rout yang kecil Rout $=0$ akan tetap melewatkan sinyal. Berdasarkan pengukuran dapat dilihat data hubungan antara besarnya beban, keluaran transformator tegangan, keluaran transformator arus, keluaran rangkaian pengali dan keluaran rangkaian penyangga pembalik sepert ditunjukkan pada Tabel 4.2 berikut:

Tabel 4. 2 Hasil pengukuran keluaran transformator tegangan, transformator arus, pengali dan penyangga pembalik

\begin{tabular}{|c|c|c|c|c|}
\hline $\begin{array}{c}\text { Beban } \\
\text { (Watt) }\end{array}$ & $\begin{array}{c}\text { Output trafo } \\
\text { tegangan } \\
\text { (volt AC) }\end{array}$ & $\begin{array}{c}\text { Output trafo } \\
\text { arus } \\
\text { (volt AC) }\end{array}$ & $\begin{array}{c}\text { Output } \\
\text { Pengali } \\
\text { (milivolt dc) }\end{array}$ & $\begin{array}{c}\text { Output penyangga } \\
\text { pembalik } \\
\text { (milivolt dc) }\end{array}$ \\
\hline 10 & 3 & 0,051 & -24 & 24 \\
\hline 20 & 3 & 0,105 & -30 & 30 \\
\hline 30 & 3 & 0,155 & -36 & 36 \\
\hline
\end{tabular}




\begin{tabular}{|l|l|l|l|l|}
\hline 40 & 3 & 0,210 & -42 & 42 \\
\hline 50 & 3 & 0,261 & -47 & 48 \\
\hline
\end{tabular}

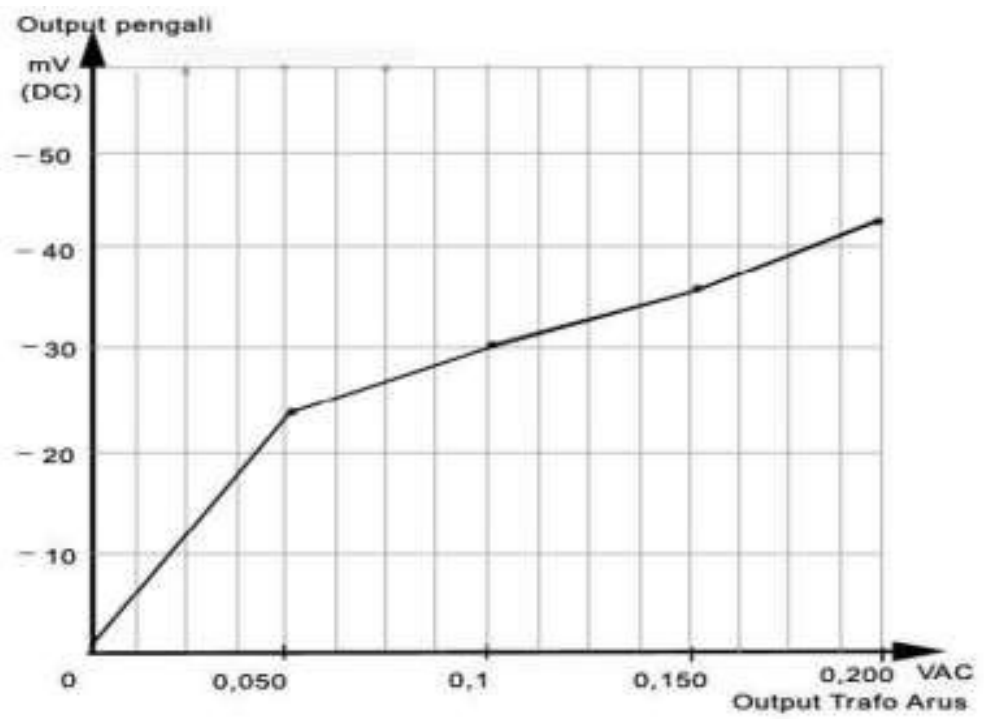

Gambar 4. 3 Grafik karakteristik hubungan antara perubahan tegangan keluaran trafo arus dan keluaran pengali (Sumber: M. Nurul Hudha).

Keluaran pembalik sudah sesuai dengan teori, sehingga dapat diumpankan rangkaian Voltage Control Oscilator VCO. Dari Tabel 4.2 dapat dibuat grafik karakteristik hubungan antara perubahan tegangan keluaran trafo arus dan keluaran pengali yang ditunjukkan pada gambar 4. 3 :

\section{Voltage Controlled Oscilator (VCO)}

Osilator yang dikendalikan tegangan (voltage cotrolled oscillator VCO) ini mampu mengeluarkan gelombang segitiga dan kotak. Seperti VCO yang lain maka frekuensi keluaran ditentukan oleh besar kecilnya tegangan kontrol Vc.

Osilator ini didasarkan pada prinsip integrator-komparator; disini kondensator $\mathrm{C} 1$ merupakan bagian dari integratornya (rangkaian sekitar A1). Kondensator tersebut disi oleh arus yang tetap, dan tarafnya ditentukan oleh taraf sesaat tegangan kontrol, Vc dan akibatnya keluaran dari pembanding (komparator) (rangkaian sekitar A2) mengubah keadaan dan transistor TL mulai menghantar, bilamana ambang alih (switching) yang rendah dicapai. Kondensator $\mathrm{C} 1$ dalam keadaan ini membuang muatannya dan menyebabkan keluaran A1 naik (sekali lagi bahwa tegangan ini naiknya linear). Proses ini diulang kembali pada saat keluaran A1 mencapai ambang alih (switching) atas dari pembanding dan TL dimatikan. Faktor aktif dari sinyal keluaran akan $50 \%$ bila nilai R2 sama dengan R3 dan bila nilai R1 dua kali lebih besar dari R4 (R2 = R3 dan R1 = $2 \times 24)$. Hubungan antara R9 dan R10 akan menentukan taraf (level) DC dari keluaran sinyal segitiga. Rangkaian akan menghasilkan frekuensi keluaran gelombang kotak $\mathrm{F}_{2}$ yang berbanding terbalik dengan tegangan kendali Vreff. Jadi semakin besar harga Vreff ${ }_{2}$ maka $\mathrm{F}_{2}$ semakin kecil. Keluaran untai ini yaitu $\mathrm{F}_{2}$ akan diumpankan ke untai kendali sebagai base time. Karena untai kendali akan menghasilkan periode waktu pengukuran yang terbalik dengan frekkuensi time base, jadi semakin besar harga Vreff ${ }_{2}$ akan semakin lama 
waktu pengukuran yang dilakukan dan semakin besar hasil pengukuran. Besarnya frekuensi osilator terkendali tegangan pada gambar diatas dapat ditentukan dengan persamaan

$$
\text { Fo }=\underline{2,5} \frac{\text { \$\$-Vreff })}{\mathrm{RC}} \quad \mathrm{Vs}
$$

Tegangan ini merupakan tegangan kontrol frekuensi yang akan diintegrasikan oleh integrator. Saat tegangan output integrator turun sedikit demi sedikit lebih kecil dari $8 / 3 \mathrm{~V}$, maka masukan komparator mendapat masukan tinggi dan membandingkannya sehingga transistor T1 jenuh. Segera setelah transistor $\mathrm{Q}_{1}$ menjadi jenuh, sehingga tegangan input integratormenjadinegatif.

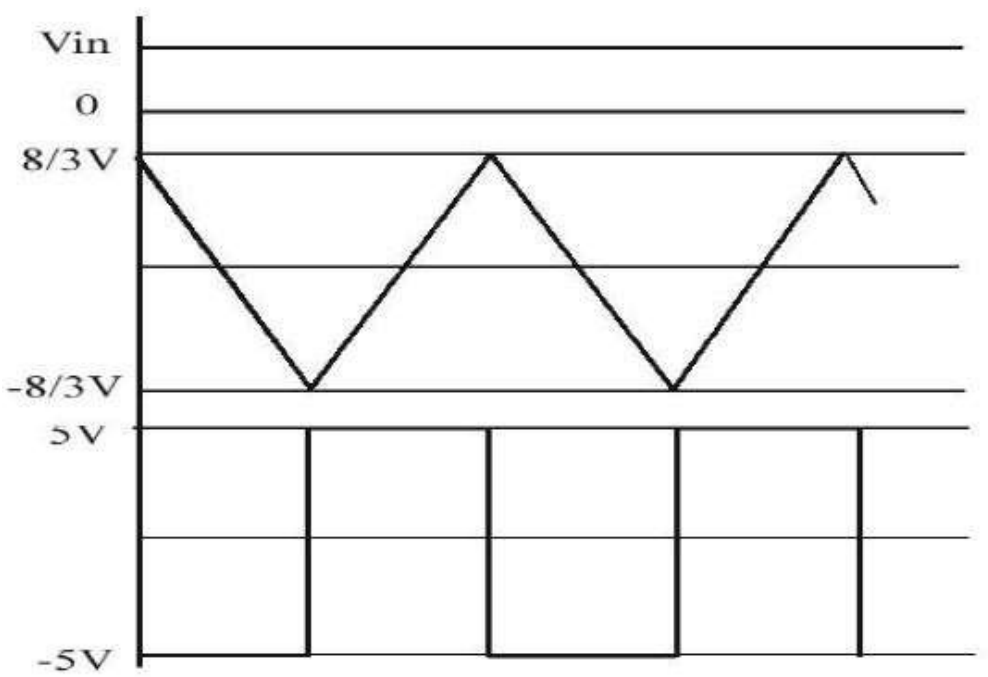

Gambar 4. 4 Bentuk gelombang VCO (Sumber: M. Nurul Hudha)

Apabila output integrator sedikit lebih besar dari $8 / 3 \mathrm{~V}$, maka masukan komparator akan membandingkan kembali kemudian kemudian memutus transisitor $\mathrm{Q}_{1}$ dan tegangan output integrator turun ke $-8 / 3 \mathrm{~V}$ lagi. Demikian terus berulang dengan frekuensi yang sebanding dengan tegangan masukan. Perbandingan output antara tegangan masukan dengan frekuensi keluaran dapat dihitung sebagai berikut :

$\mathrm{T}_{1}$ merupakan lebar pulsa negatif

$\mathrm{T}_{2}$ merupakan lebar pulsa positif

Dengan R1=R2, maka dapat dihitung :

Saat T1 keluaran integrator turun dari $+8 / 3 \mathrm{~V}$ ke $-8 / 3 \mathrm{~V}$

$-8 / 3$

$-16 / 3$

$$
\begin{aligned}
& =8 / 3-\mathrm{Vin} \mathrm{T} 1 /(4 \mathrm{RC}) \\
& =-\mathrm{Vin} \mathrm{T} 1 /(4 \mathrm{RC}) \\
\mathrm{T} 1 & =\frac{64 \mathrm{RC}}{3 \mathrm{Vin}}
\end{aligned}
$$

Sedang saat $\mathrm{T} 2$, tegangan integator naik dari $-8 / 3 \mathrm{~V} \mathrm{ke}+8 / 3 \mathrm{~V}$, integrator berada dalam keadaan jenuh (on) sehingga tegangan masukan integrator adalah Vth

$$
\begin{aligned}
\text { Vth } & =\mathrm{Vin} / 3-\mathrm{Vin} / 2 \\
\mathrm{Vth} & =-\mathrm{Vin} / 6 \\
\mathrm{Rth} & =2 \mathrm{R} / / \mathrm{R} \\
& =2 \mathrm{R} / 3
\end{aligned}
$$


T2 dapat dihitung sebagai berikut;

$$
\begin{aligned}
& 8 / 3=-8 / 3(-\mathrm{Vin} \mathrm{T} 2 / 6) /(2 \mathrm{RC} / 3) \mathrm{dt} \\
& 16 / 3=\mathrm{Vin} \mathrm{T} 2 / 4 \mathrm{RC} \\
& \mathrm{T} 2=64 \mathrm{RC} / 3 \mathrm{Vin} \\
& \mathrm{T} 1 \quad=\mathrm{T} 2 \\
& \text { Periode } \mathrm{T} 1+\mathrm{T} 2 \\
& =128 \mathrm{RC} / 3 \mathrm{Vin} \\
& \mathrm{F}=3 \mathrm{Vin} /(128 \mathrm{RC}) \\
& \mathrm{F}=0,0234375 \mathrm{Vin} / \mathrm{RC}
\end{aligned}
$$

Dari salah satu rangkaian, untuk beberapa contoh beban terpasang dapat dibuat 1 perbandingan hasil pengukuran antara berbagai beban terpasang, tegangan masukan dan frekuensi keluaran yang dihasilkan oleh VCO sebagai berikut: 78

Tabel 4.3 Perbandingan antara beban, masukan dan keluaran VCO

\begin{tabular}{|c|c|c|}
\hline $\begin{array}{c}\text { Beban Terpasang } \\
\text { (Watt) }\end{array}$ & $\begin{array}{c}\text { Tegangan masukan VCO } \\
\text { (mvolt) }\end{array}$ & $\begin{array}{c}\text { Frekuensi keluaran VCO } \\
(\mathrm{Hz})\end{array}$ \\
\hline 10 & 27 & 1,9 \\
\hline 20 & 31 & 4,0 \\
\hline 40 & 42 & 8,3 \\
\hline 50 & 48 & 10,0 \\
\hline 60 & 53 & 12,6 \\
\hline
\end{tabular}

Dari tabel tersebut dapat dibuat grafik hubungan antara masukan tegangan VCO dan frekuensi keluaran VCO pada gambar 4. 5 :

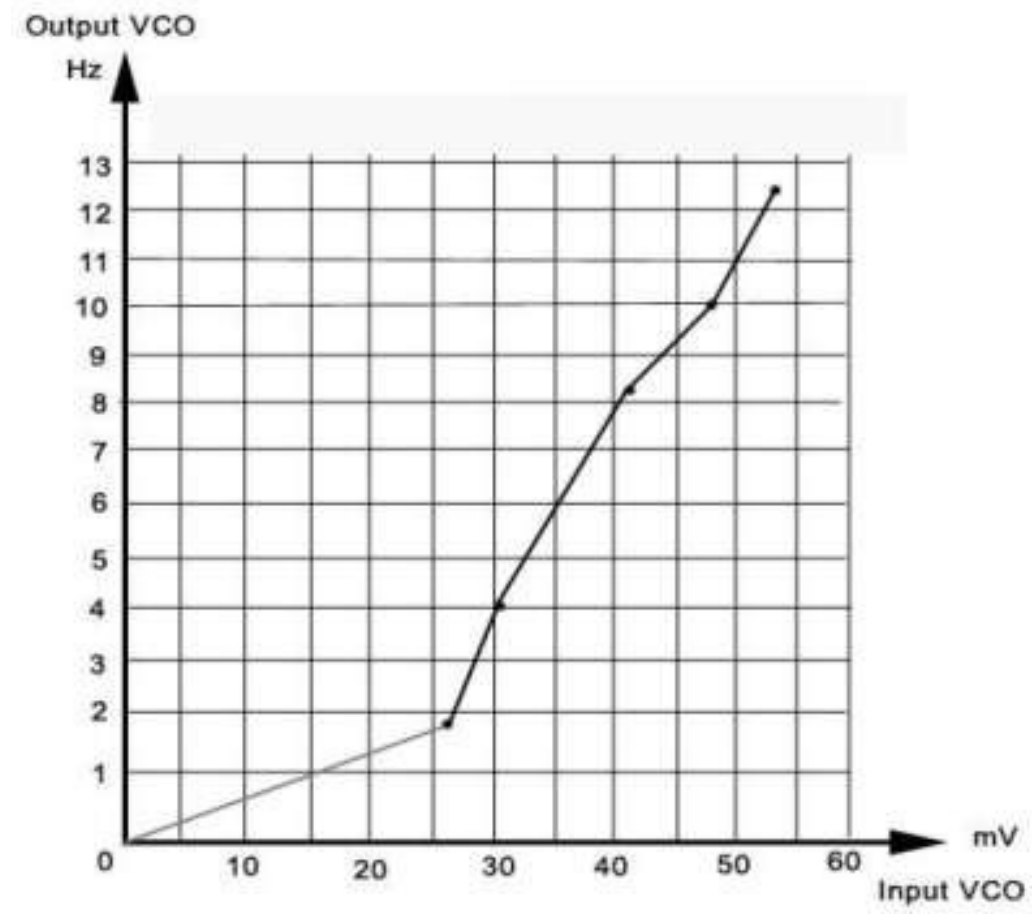

Gambar 4. 5 Grafik hubungan antara masukan tegangan dan frekuensi keluaran Voltage Controlled Oscilatror/VCO (Sumber: M. Nurul Hudha) 


\section{Data Sistem Minimum Mikrokontroler 89C51 Data Masukan Counter Gelombang}

Mode 1 - Pencacah Biner 16 bit

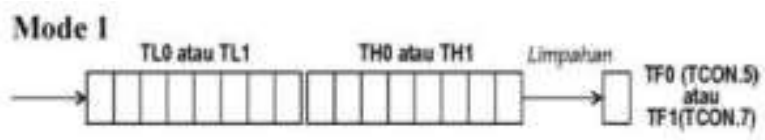

Gambar Mode 1 - Pencacah Biner 16 Bit (Sumber: M. Nurul Hudha)

Mode ini sama dengan Mode 0, hanya saja register TLx dipakai sepenuhnya sebagai pencacah biner 8 bit, sehingga kapasitas pencacah biner yang tersbentuk adalah 16 bit. Seiring dengan sinyal denyut, kedudukan pencacah biner 16 bit ini akan bergerak dari \$0000 (biner 000000000000 0000), \$0001, \$0002 ... sampai \$FFFF (biner 11111111 1111 1111), kemudian melimpah kembali menjadi $\$ 0000$. Pada potongan program counter sudah ditetapkan bahwa data akan melimpah setelah terdapat dua pulsa. Untuk mendapatkan hal ini, maka pada TL1 dan TH1 diisi data 1111111111111101 biner atau FFFD heksadesimal.

\section{Pengaturan Harga Daya Listrik (Kwh)}

Penetapan harga per Kwh dapat diatur dengan mudah, karena nilai yang dimasukkan pada program adalah nilai bilangan desimal yang dipresentasikan kedalam bilangan heksadesimal.

Sebagai contoh harga per kwh adalah 34. data yang diisikan sebenarnya adalah data heksadesimal, akan tetapi dapat mempresentasikan data bilangan desimal. Hal itu dapat jelaskan sebagai berikut :

$$
34 \mathrm{~h}=000110100
$$

Untuk mendapatkan 4, maka bilangan 34h dikalikan $01 \mathrm{~h}=00001111$ biner $=04$ desimal. Untuk mendapatkan 3, maka 34h ditukar (swap) dan dikalikan 01h. Hal ini berlaku untuk nomor kamar, gelombang dan voucher.

\section{KESIMPULAN DAN SARAN}

Setelah melaksanakan perancangan, pembuatan dan pengamatan serta pengujian alat, dapat ditarik beberapa kesimpulan sebagai berikut : 1)Pengukuran daya dilakukan dengan mengalikan parameter tegangan dan arus, kemudian mengkonversikan kedalam frekuensi. Dengan metode ini. 2) Program perhitungan daya dengan counter mempunyai keuntungan range frekuensi yang lebar sehingga dapat mengukur daya lebih sensitif dan lebih besar. 3) Perhitungan besar Kwh yang dipakai dapat diatur oleh operator dengan mengubah program pada mikrokontroler. 4) Pemakai atau pelanggan listrik dapat dengan mudah mengetahui besarnya daya yang dipakai, sisa pulsa serta dapat pula melakukan pengisian nomor pin voucher pada keypad yang ada dimasing-masing kamar pelanggan. 5) Dalam pengembangan ke depan, selain untuk pengukuran daya listrik alat ini diharapkan mampu mengukur parameter-parameter lain misalnya pemakaian air dan pemakaian telepon.

Untuk mengoperasikan alat ini ada beberapa hal yang perlu diperhatikan, yaitu : 1) Pengukuran daya listrik pada alat ini mempergunakan metoda yang sangat sederhana, yakni mengalikan parameter tegangan dan parameter arus, tanpa memperhitungkan faktor dayanya sehingga tidak sesuai untuk jangkauan daerah yang lebih luas. 2) Karena komponen-komponen yang digunakan pada alat ini kurang ideal, maka parameter-parameter yang dihasilkan juga tidak sempurna. 3) Pengaturan dan pengesetan variabel resistor pada rangkaian pengali harus 
dilakukan dan sangat menentukan sinyal keluaran rangkaian pengali. 4) Kecepatan respon rangkaian Voltage Controlled Oscilator/VCO terhadap perubahan tegangan masukan relatif kurang cepat, sehingga perubahan masukan counter pada mikrokontroler juga lambat. Akan tetapi hal ini tidak begitu berpengaruh dengan perbandingan daya yang diukur.

\section{DAFTAR PUSTAKA}

Agfianto Eko Putra, 2002, Belajar Mikrokontroller AT89C51, Gaya Media, Yogyakarta.

Coughlin, Robert F Driscoll, Frederick F, 1992, Penguat Operasional dan Rangkaian Terpadu, Edisi Kedua, PT. Erlangga, Jakarta.

Hogenboom P, 1996, Data Sheet Book 4, PT. Elex Media Komputindo, Jakarta.

Malvino Paul, Albert, Ph.D.,1992, Prinsip-Prinsip Elektronika, Edisi Ketiga, PT. Erlangga, Jakarta.

Malvino Paul, Albert, Ph.D.,1992, Elektronika Komputer Digital Pengantar Mikrokomputer, Edisi Kedua, PT. Erlangga, Jakarta.

Milman Jacob, Sutanto, 1996, Mikroelektronika Sistem Digital dan Rangkaian Analog, Erlangga, Jakarta.

M.Nurul Hudha M ,2004 Dalam Kwh meter digital untuk aplikasi automatisasi pencatatan pemakaian daya listrik. UGM Yogyakarta.

Toklen, Roger L, 1994, Prinsip-Prinsip Digital, Edisi Kedua, PT. Erlangga, Jakarta.

Wasito S., 1986, Vedemekum Elektronika, PT. Gramedia, Jakarta. 